\title{
Accumulation of heavy metals in the organs of herbaceous plants
}

\author{
Antonina Reut*, Aigul Biglova, and Irina Allayarova \\ South-Ural Botanical Garden-Institute of Ufa Federal Research Centre of Russian Academy of \\ Sciences, 450080, Mendeleev str., 195/3, Ufa, Russia
}

\begin{abstract}
The purpose of the work is to establish the characteristics of the accumulation of heavy metals of aboveground and underground organs in plant samples of 8 varieties of Narcissus hybridus and Camassia cusickii in the urbanized environment of the city of Ufa. The study of the elemental composition of the samples was carried out according to the method of quantitative chemical analysis 'Determination of $\mathrm{As}, \mathrm{Pb}, \mathrm{Cd}, \mathrm{Sn}, \mathrm{Cr}, \mathrm{Cu}$, $\mathrm{Fe}, \mathrm{Mn}$ and $\mathrm{Ni}$ in laboratory samples of food products and food raw materials by the atomic absorption method with electrothermal atomization'. It was found that the content of nickel, copper, cadmium, lead, magnesium, iron, chromium in all the samples studied does not exceed the standards specified in the State Pharmacopoeia of the Russian Federation (SP RF). The arsenic content exceeds the standards specified in the SP RF by 3.4 times. Revealed a high intensity of biological absorption of copper. It has been established that the concentrations of $\mathrm{As}, \mathrm{Cu}, \mathrm{Pl}, \mathrm{Mn}$, $\mathrm{Fe}$ in the aboveground organs are higher than in the underground part of plants; the ratio of the content of $\mathrm{Ni}, \mathrm{Cr}, \mathrm{Cd}$ in aboveground and underground organs is the same.
\end{abstract}

\section{Introduction}

The ecological state of the urban environment has a significant impact on human life. Heavy metals (HM) occupy a special place among the large number of various chemical substances that enter the environment as a result of natural and man-made impacts [1]. HM are among the most widespread and dangerous for biota environmental pollutants [2]. On the one hand, they are necessary for the normal course of physiological processes, and on the other hand, at high concentrations of HM, they are toxic $[3,4,5]$. In this regard, the determination of the level of HM content in plants plays an important role in the assessment of biogenic migration and is necessary for control for their environmentally safe use [6].

To date, the scientific literature describes many methods for cleaning soil from HM contamination. However, most of them are aimed at restoring agricultural soils and have not found practical application in urban conditions. Ornamental flower crops, which firmly occupy their ecological niche, are practically not considered from this point of view $[7,8]$.

In connection with the above, it is important to establish the features of HM accumulation and to determine the elemental composition of aboveground (leaves) and

\footnotetext{
*Corresponding author: cvetok.79@mail.ru
} 
underground (bulbs) organs in plant samples of 8 varieties of Narcissus hybridus hort. ('Actaea', 'Arctic Gold', 'Cassata', 'Quail', 'Sir Winston Churchill', 'White Lady', 'Calgary' and 'Pink Parasol') and Camassia cusickii S. Wats. in the urbanized environment of the city of Ufa.

\section{Methods}

The study was carried out on the basis of the South-Ural Botanical Garden-Institute of Ufa Federal Research Centre of Russian Academy of Sciences (hereinafter SUBSI UFRC RAS) in the spring-summer period of 2018-2020.

Narcissus are perennial ornamental bulbous plants belonging to the genus Narcissus L., of the family Amaryllidaceae J.St.-Hil. Distributed in Central Europe, the Mediterranean, China and Japan. They are widely used in landscaping urban areas, and also used in medicine and perfumery (contains alkaloids and essential oils) [9]. Camassia is a promising perennial ornamental bulbous plant belonging to the genus Camassia Lindl., of the family Hyacinthaceae Batsch. Distributed in the temperate zones of North America. The name is borrowed from the North American Indians who eat bulbs [10].

The study of the elemental composition of the samples was carried out according to the method of quantitative chemical analysis "Determination of $\mathrm{As}, \mathrm{Pb}, \mathrm{Cd}, \mathrm{Sn}, \mathrm{Cr}, \mathrm{Cu}, \mathrm{Fe}, \mathrm{Mn}$ and $\mathrm{Ni}$ in laboratory samples of food products and food raw materials by atomic absorption method with electrothermal atomization No. M-02-1009-08" [11]. The selection of plant samples was carried out during the period of full development of the leaf blade in the flowering phase for Narcissus cultivars and in the fruit setting phase for Camassia cusickii (III decade of May). The samples were dried to an air-dry state at room temperature and then mechanically crushed. The mass of the laboratory sample was $50 \mathrm{~g}$. The study of the elemental composition was carried out with an atomic absorption spectrophotometer (spectrometer) Shimadzu AA-6800 (or AA-6300) with an electrothermal atomizer GFA EX-7, registered in the State Register of measuring instruments under No. 19381-04, based on analytical laboratory of the research institute of agriculture.

Mathematical processing of the data was carried out using generally accepted methods of variation statistics using the Microsoft Excel software package.

\section{Results}

Arsenic. Analysis of the content of arsenic in the studied plants showed that in the aboveground organs of narcissus and camassia, its concentration varies from $0.24 \mathrm{mg} / \mathrm{kg}$ ('Actaea') to 1.08 ('Cassata'), in underground - from $0.27 \mathrm{mg} / \mathrm{kg}$ ('Calgary') to 1.70 ('White Lady'). The average content of the element in the aboveground parts is $0.76 \mathrm{mg} / \mathrm{kg}$, in the underground $-0.70 \mathrm{mg} / \mathrm{kg}$. The varieties 'Actaea', 'Sir Winston Churchill', 'White Lady' have the greatest amount of arsenic in underground organs; in 'Pink Parasol' - the ratio of the content of the element in the studied parts of the plant was found in equal amounts; the rest - in the aboveground (fig. 1).

It was revealed that the content of arsenic exceeds the norms specified in the domestic pharmacopoeia $(0.50 \mathrm{mg} / \mathrm{kg})$ [12]. An increased concentration of As was found in the leaves of most of the studied narcissus cultivars by 2.2 times, except for 'Actaea' and the species Camassia cusickii. The cultivars 'Actaea', 'Sir Winston Churchill', 'White Lady', 'Pink Parasol' also have As content in bulbs 3.4 times higher than the maximum permissible concentration (MPC). Presumably, the studied cultivars can accumulate a noticeable amount of arsenic in leaves and bulbs. 
Cadmium. In accordance with the State Pharmacopoeia of the Russian Federation (SP $\mathrm{RF}$ ), the cadmium content rate is $1 \mathrm{mg} / \mathrm{kg}$ [12]. It was revealed that the concentration of cadmium in the studied taxa does not exceed the MPC: in the aboveground organs it contains from $0.01 \mathrm{mg} / \mathrm{kg}$ ('Actaea', 'Arctic Gold', 'Pink Parasol', Camassia cusickii) to 0.04 ('Quail'); in underground - from $0.00 \mathrm{mg} / \mathrm{kg}$ for 'Calgary' to 0.04 ('Sir Winston Churchill'). The average cadmium content in aboveground and underground organs is 0.02 $\mathrm{mg} / \mathrm{kg}$. The cultivars 'Cassata', 'Quail', 'Calgary' have the highest amount of $\mathrm{Cd}$ in aerial organs; 'Actaea', 'Arctic Gold', 'Sir Winston Churchill' - in underground; in other taxa, the content of the element is in equal amounts (fig. 2).

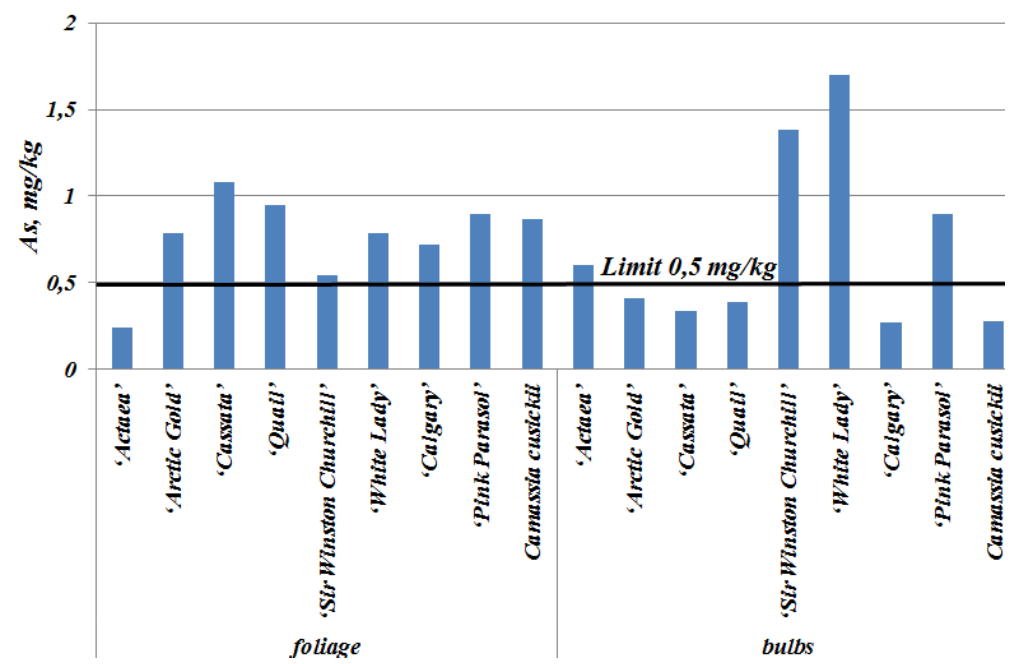

Fig. 1. Content of arsenic in the aboveground and underground organs of Narcissus and Camassia

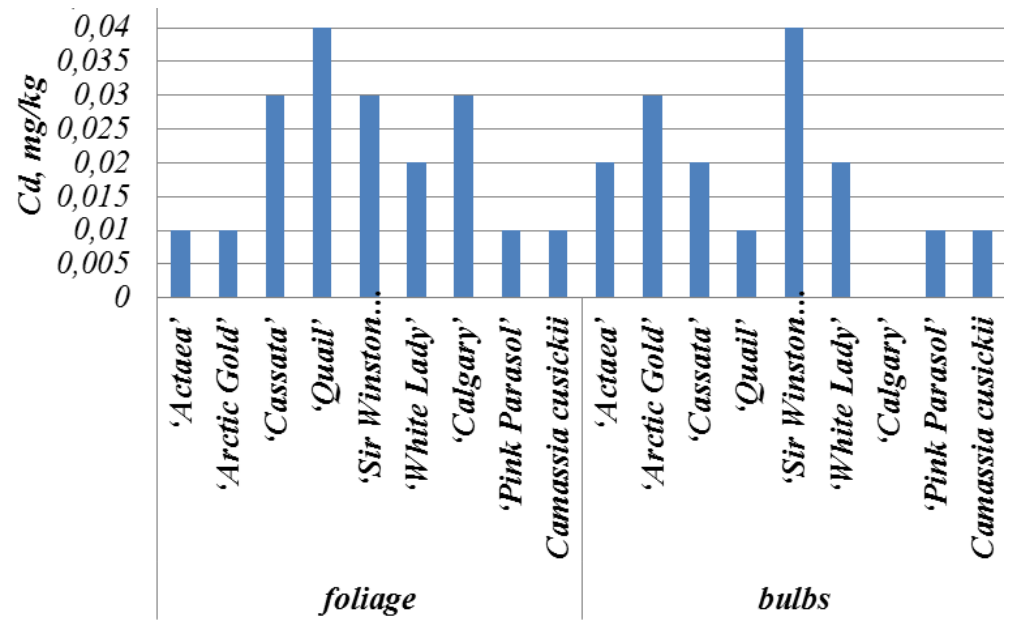

Fig. 2. Content of cadmium in the aboveground and underground organs of Narcissus and Camassia

Lead. In accordance with the State Pharmacopoeia of the Russian Federation, the MPC for lead in medicinal plant materials is $6 \mathrm{mg} / \mathrm{kg}$. The $\mathrm{Pb}$ content in the aboveground organs of the studied plants varies from $0.63 \mathrm{mg} / \mathrm{kg}$ (Camassia cusickii) to 1.82 ('Quail'); in bulbs - from $0.59 \mathrm{mg} / \mathrm{kg}$ ('Actaea') to 1.01 ('Pink Parasol'). The average content of the element in the aboveground organs is $0.99 \mathrm{mg} / \mathrm{kg}$, in the underground $-0.78 \mathrm{mg} / \mathrm{kg}$, i.e. the lead content does not exceed the MPC [12]. Camassia cusickii and the 'Arctic Gold' 
cultivar contain the greatest amount of $\mathrm{Pb}$ in the underground organs, while the rest - in the aboveground ones (fig. 3).

Manganese. Analysis of the manganese content in plants showed that in the aboveground parts its concentration ranges from $0.60 \mathrm{mg} / \mathrm{kg}$ ('Actaea') to 0.75 (Camassia cusickii), and in underground parts - from $0.61 \mathrm{mg} / \mathrm{kg}$ (Camassia cusickii, 'Actaea') to 0.78 ('Sir Winston Churchill'). The average content of the element in the aboveground organs is $0.69 \mathrm{mg} / \mathrm{kg}$, in the underground $-0.67 \mathrm{mg} / \mathrm{kg}$, i.e. there is a deficiency of manganese (MPC $-25 \mathrm{mg} / \mathrm{kg}$ ) $[13,14]$. The varieties 'Actaea', 'Sir Winston Churchill', 'Calgary' have the greatest amount of manganese in underground organs; in the 'White Lady', the content of the element in both underground and aboveground organs is equal; the rest - in the aboveground (fig. 4).

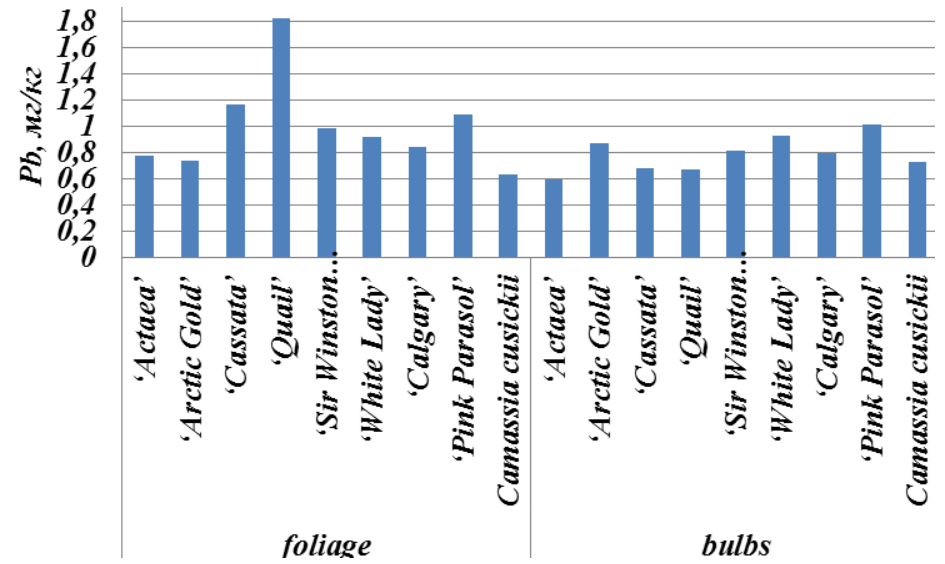

Fig. 3. Content of lead in the aboveground and underground organs of Narcissus and Camassia

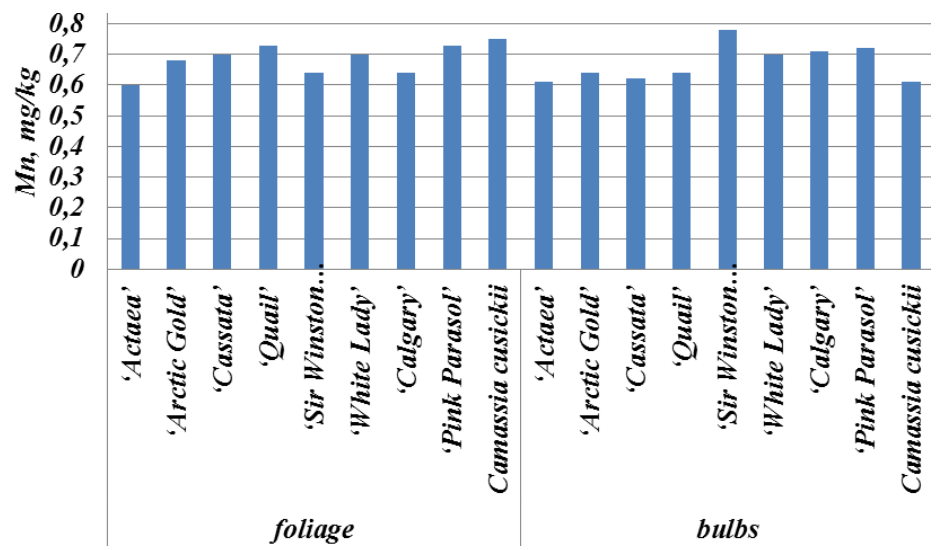

Fig. 4. Content of magnesium in the aboveground and underground organs of Narcissus and Camassia

Iron. Analysis of the iron content in plants showed that in the aboveground parts, its concentration varies from $0.47 \mathrm{mg} / \mathrm{kg}$ ('Calgary') to 0.64 ('Quail'), and in underground parts - from $0.38 \mathrm{mg} / \mathrm{kg}$ ('White Lady') to 0.58 ('Arctic Gold'). The average content of the element in the aboveground organs is $0.55 \mathrm{mg} / \mathrm{kg}$, in the underground $-0.51 \mathrm{mg} / \mathrm{kg}$, i.e. iron deficiency is noted (MPC - 5-15 mg/kg) [15]. The 'Actaea', 'Arctic Gold', 'Cassata', 'Calgary' varieties contain the greatest amount of iron in the underground organs, while the rest - in the aboveground ones (fig. 5). 
Nickel. Analysis of the nickel content in plants showed that in the aboveground parts the concentration ranges from $0.37 \mathrm{mg} / \mathrm{kg}$ ('Actaea') to 0.84 ('Quail'), and in the underground parts - from $0.29 \mathrm{mg} / \mathrm{kg}$ (Camassia cusickii) up to 1.06 ('Sir Winston Churchill'). The average content of the element in aboveground and underground organs is $0.67 \mathrm{mg} / \mathrm{kg}$. It was revealed that the concentration of nickel in the studied taxa does not exceed the temporary maximum permissible level (MRL) in feed for farm animals and feed additives (1-3 mg/kg) [16]. The 'Actaea', 'Sir Winston Churchill', 'White Lady', 'Calgary' cultivars contain the greatest amount of nickel in underground organs, while the rest - in aboveground ones (fig. 6).

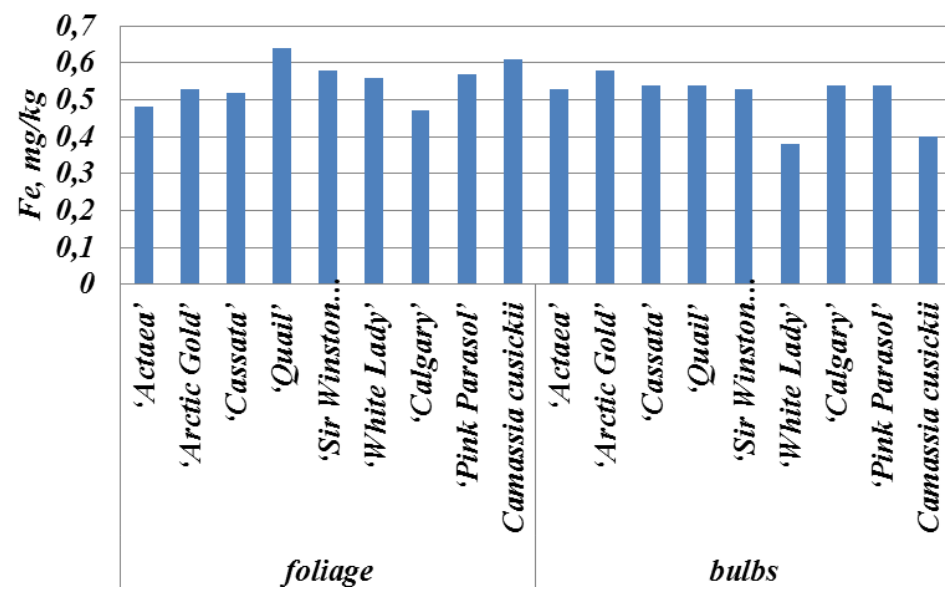

Fig. 5. Content of iron in the aboveground and underground organs of Narcissus and Camassia

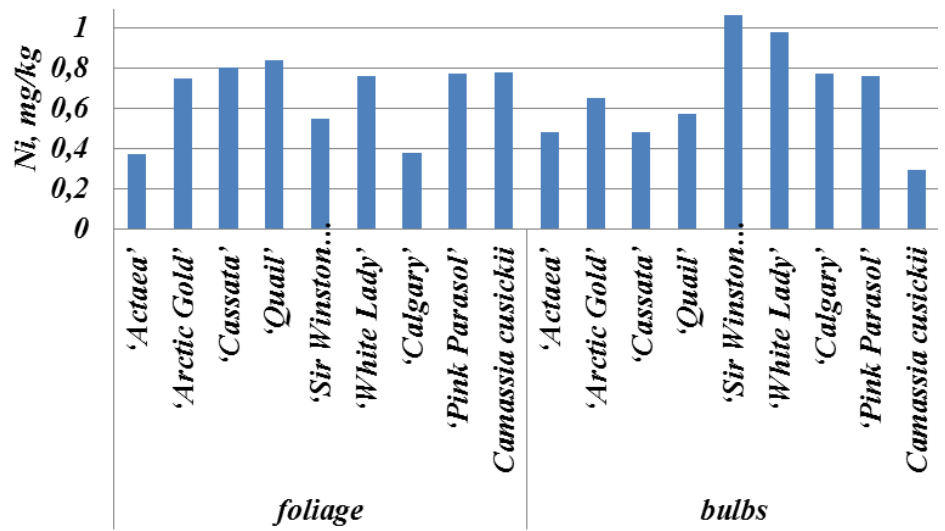

Fig. 6. Content of nickel in the aboveground and underground organs of Narcissus and Camassia

Copper. Analysis of the copper content in plants showed that in the aboveground parts, the concentration varies from $8.28 \mathrm{mg} / \mathrm{kg}$ ('Pink Parasol') to 24.02 ('Sir Winston Churchill'), and in underground parts - from $1.60 \mathrm{mg} / \mathrm{kg}$ ('White Lady') to 19.48 ('Quail'). The average content of the element in the aboveground organs is $14.86 \mathrm{mg} / \mathrm{kg}$, in the underground $-12.48 \mathrm{mg} / \mathrm{kg}$. It was revealed that the concentration of copper in the studied taxa does not exceed the MRL (20-30 mg/kg) [16] and the MPC SanPiN (25 mg/kg) [15]. The varieties 'Arctic Gold', 'Cassata', 'Quail' and Camassia cusickii contain the largest amount of copper in the underground organs, while the rest - in the aboveground ones (fig. $7)$. 
Chromium. Analysis of the chromium content in plants showed that in the aboveground parts the concentration varies from $0.04 \mathrm{mg} / \mathrm{kg}$ ('Actaea') to 0.25 ('Quail'), in the underground - from $0.05 \mathrm{mg} / \mathrm{kg}$ ('White Lady') to 0.22 ('Sir Winston Churchill'). The average content of the element in aboveground and underground organs is $0.13 \mathrm{mg} / \mathrm{kg}$, which does not exceed the MRL $(0.5-1 \mathrm{mg} / \mathrm{kg}$ ). The varieties 'White Lady', 'Quail' and the species Camassia cusickii contain the greatest amount of chromium in the above-ground organs, while the rest are in the underground (fig. 8).

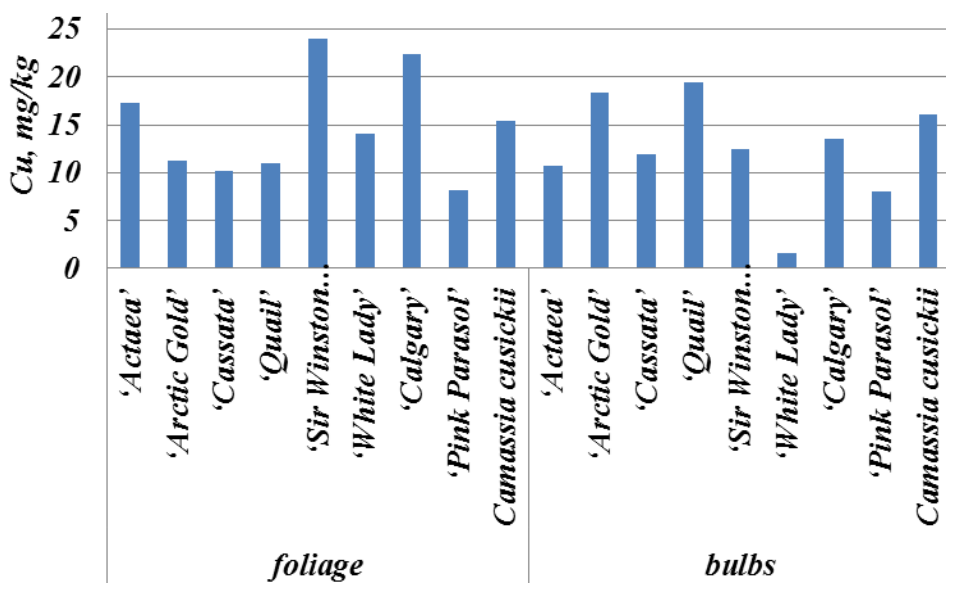

Fig. 7. Content of copper in the aboveground and underground organs of Narcissus and Camassia

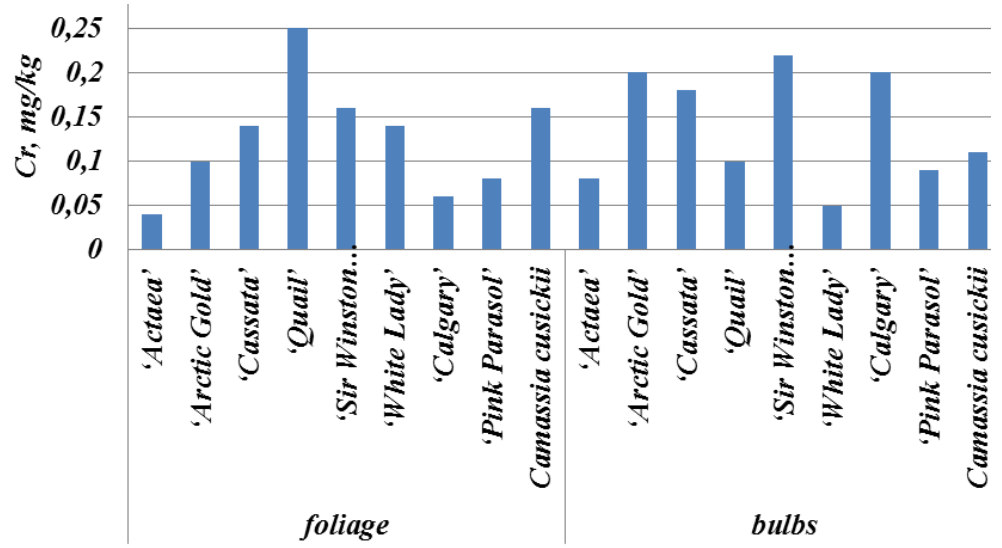

Fig. 8. Content of chromium in the aboveground and underground organs of Narcissus and Camassia

The research results showed the following regularity in the change in the content of elements in plant samples. Copper predominates in all the samples studied, with the exception of the 'White Lady' bulbs, which contain more arsenic. Lead is the second most abundant, except for 'Actaea' underground organs, which have more manganese, and 'Sir Winston Churchill' bulbs and 'Arctic Gold' leaves and Camassia cusickii, which have more arsenic. It was revealed that the concentration of chromium and cadmium is always minimal.

It was shown that plants accumulate elements in underground and aboveground organs in different ways. According to the quantitative content in the aboveground organs of the varieties 'Cassata', 'Quail', 'White Lady', 'Pink Parasol', 'Calgary', the elements are arranged in the following order: $\mathrm{Cu}>\mathrm{Pb}>\mathrm{As}>\mathrm{Ni}>\mathrm{Mn}>\mathrm{Fe}>\mathrm{Cr}>\mathrm{Cd}$. The exception is 'Calgary', where nickel accumulates less than manganese and iron (table). 
According to the content in underground organs of the 'Arctic Gold' and 'Calgary' varieties, the elements are arranged in the following order: $\mathrm{Cu}>\mathrm{Pb}>\mathrm{Ni}>\mathrm{Mn}>\mathrm{Fe}>\mathrm{As}>\mathrm{Cr}>\mathrm{Cd}$ (table 1).

Considering the accumulation of heavy metals in plant organs, it can be noted that the average content of $\mathrm{As}, \mathrm{Cu}, \mathrm{Pb}, \mathrm{Mn}, \mathrm{Fe}$ is higher in the aboveground parts. The ratio of the average content of $\mathrm{Ni}, \mathrm{Cr}, \mathrm{Cd}$ in the aboveground and underground organs is the same. Thus, the accumulation capacity of aboveground organs is higher than or equal to that of bulbs of the same taxa. According to the literature data, it was found that on unpolluted soils the least amount of heavy metals is characteristic of the storage organs [14].

Table 1. Series of accumulation of elements in aboveground and underground organs of Narcissus and Camassia

\begin{tabular}{|l|l|l|}
\hline \multicolumn{1}{|c|}{ Taxons } & Material & The ranks of the accumulation \\
\hline \multirow{2}{*}{ 'Actaea' } & foliage & $\mathrm{Cu}>\mathrm{Pb}>\mathrm{Mn}>\mathrm{Fe}>\mathrm{Ni}>\mathrm{As}>\mathrm{Cr}>\mathrm{Cd}$ \\
\cline { 2 - 3 } & bulbs & $\mathrm{Cu}>\mathrm{Mn}>\mathrm{As}>\mathrm{Pb}>\mathrm{Fe}>\mathrm{Ni}>\mathrm{Cr}>\mathrm{Cd}$ \\
\hline \multirow{2}{*}{ 'Arctic Gold' } & foliage & $\mathrm{Cu}>\mathrm{As}>\mathrm{Ni}>\mathrm{Pb}>\mathrm{Mn}>\mathrm{Fe}>\mathrm{Cr}>\mathrm{Cd}$ \\
\cline { 2 - 3 } & bulbs & $\mathrm{Cu}>\mathrm{Pb}>\mathrm{Ni}>\mathrm{Mn}>\mathrm{Fe}>\mathrm{As}>\mathrm{Cr}>\mathrm{Cd}$ \\
\hline \multirow{2}{*}{ 'Cassata' } & foliage & $\mathrm{Cu}>\mathrm{Pb}>\mathrm{As}>\mathrm{Ni}>\mathrm{Mn}>\mathrm{Fe}>\mathrm{Cr}>\mathrm{Cd}$ \\
\cline { 2 - 3 } & bulbs & $\mathrm{Cu}>\mathrm{Pb}>\mathrm{Mn}>\mathrm{Fe}>\mathrm{Ni}>\mathrm{As}>\mathrm{Cr}>\mathrm{Cd}$ \\
\hline 'Quail' & foliage & $\mathrm{Cu}>\mathrm{Pb}>\mathrm{As}>\mathrm{Ni}>\mathrm{Mn}>\mathrm{Fe}>\mathrm{Cr}>\mathrm{Cd}$ \\
\cline { 2 - 3 } & bulbs & $\mathrm{Cu}>\mathrm{Pb}>\mathrm{Mn}>\mathrm{Ni}>\mathrm{Fe}>\mathrm{As}>\mathrm{Cr}>\mathrm{Cd}$ \\
\hline \multirow{3}{*}{ 'Sir Winston Churchill' } & foliage & $\mathrm{Cu}>\mathrm{Pb}>\mathrm{Mn}>\mathrm{Fe}>\mathrm{Ni}>\mathrm{As}>\mathrm{Cr}>\mathrm{Cd}$ \\
\cline { 2 - 3 } & bulbs & $\mathrm{Cu}>\mathrm{As}>\mathrm{Ni}>\mathrm{Pb}>\mathrm{Mn}>\mathrm{Fe}>\mathrm{Cr}>\mathrm{Cd}$ \\
\hline \multirow{3}{*}{ 'White Lady' } & foliage & $\mathrm{Cu}>\mathrm{Pb}>\mathrm{As}>\mathrm{Ni}>\mathrm{Mn}>\mathrm{Fe}>\mathrm{Cr}>\mathrm{Cd}$ \\
\cline { 2 - 3 } & bulbs & $\mathrm{As}>\mathrm{Cu}>\mathrm{Ni}>\mathrm{Pb}>\mathrm{Mn}>\mathrm{Fe}>\mathrm{Cr}>\mathrm{Cd}$ \\
\hline 'Calgary' & foliage & $\mathrm{Cu}>\mathrm{Pb}>\mathrm{As}>\mathrm{Mn}>\mathrm{Fe}>\mathrm{Ni}>\mathrm{Cr}>\mathrm{Cd}$ \\
\cline { 2 - 3 } & bulbs & $\mathrm{Cu}>\mathrm{Pb}>\mathrm{Ni}>\mathrm{Mn}>\mathrm{Fe}>\mathrm{As}>\mathrm{Cr}>\mathrm{Cd}$ \\
\hline 'Pink Parasol' & foliage & $\mathrm{Cu}>\mathrm{Pb}>\mathrm{As}>\mathrm{Ni}>\mathrm{Mn}>\mathrm{Fe}>\mathrm{Cr}>\mathrm{Cd}$ \\
\cline { 2 - 3 } & bulbs & $\mathrm{Cu}>\mathrm{Pb}>\mathrm{As}>\mathrm{Ni}>\mathrm{Mn}>\mathrm{Fe}>\mathrm{Cr}>\mathrm{Cd}$ \\
\hline Camassia cusickii & foliage & $\mathrm{Cu}>\mathrm{As}>\mathrm{Ni}>\mathrm{Mn}>\mathrm{Pb}>\mathrm{Fe}>\mathrm{Cr}>\mathrm{Cd}$ \\
\cline { 2 - 3 } & bulbs & $\mathrm{Cu}>\mathrm{Pb}>\mathrm{Mn}>\mathrm{Fe}>\mathrm{Ni}>\mathrm{As}>\mathrm{Cr}>\mathrm{Cd}$ \\
\hline
\end{tabular}

Analysis of visual observations showed that no disturbances in the development of plants are observed (there are no signs of oppression or abnormal growth in growth). It was found that in terms of the content of elements, in particular nickel, copper, cadmium, lead, magnesium, iron, chromium, the studied samples of Narcissus and Camassia raw materials correspond to the maximum permissible concentrations. The arsenic content exceeds the MPC for medicinal plant materials $(0.50 \mathrm{mg} / \mathrm{kg})$ by 3.4 times. Nevertheless, the studied taxa are highly resistant to the accumulation of a toxic element (As) in large quantities without a noticeable effect on the appearance and metabolism. Variety specificity was noted in the content of elements in bulbs and leaves.

\section{Discussion and conclusion}

As a result of the analysis, it was revealed that the content of nickel, copper, cadmium, lead, magnesium, iron, chromium in all studied samples does not exceed the standards established in the State Pharmacopoeia of the Russian Federation.

It is shown that the content of arsenic exceeds the standards specified in the domestic pharmacopoeia by 3.4 times. Nevertheless, the studied taxa are highly resistant to the accumulation of a toxic element (As) in large quantities without a noticeable effect on the appearance and metabolism. 
Variety specificity in the content of elements in aboveground and underground organs was noted. Considering the accumulation by plant organs, it can be noted that basipetal elements for most plants, according to averaged data, are $\mathrm{As}, \mathrm{Cu}, \mathrm{Pb}, \mathrm{Mn}, \mathrm{Fe}$.

It was revealed that copper predominates in all types of raw materials, except for the 'White Lady' bulbs. The concentration of chromium and cadmium is always minimal.

The research results make it possible to classify the studied varieties Narcissus and Camassia cusickii as an arsenic hyperaccumulator and to use these taxa in phytoremediation technologies in urban areas.

The results obtained may be of interest in the field of monitoring the ecological situation in the cultivation zone of the studied plants.

This work was carried out under the Program of Basic Research of the Presidium of the Russian Academy of Sciences "Biodiversity of Natural Systems and Biological Resources of Russia" and within the framework of the state assignment of the SUBGI UFRC RAS on the topic AAAA-A18118011990151-7.

\section{References}

1. L.L. Sedelnikova, O.V. Chankina, KrasGau Bulletin, 2, 34-43 (2016).

2. L.L. Sedelnikova, O.V. Chankina, Scientific notes of ZabGU, 12, 45-51 (2017).

3. V.M. Shchukin, N.E. Kuzmina, Yu.N. Shvetsova, A.I. Luttseva, Bulletin of the Scientific Center for Expertise of Medicinal Products, 10, 41-50 (2020).

4. N.G. Bazarnova, L.I. Tikhomirova, A.A. Sinitsyna, I.V. Afanasenkova, Chemistry of plant raw materials, 4, 137-144 (2017).

5. V.Ya. Yatsyuk, O.A. Eletskaya, Scientific bulletin of BelSU. Ser. Medicine. Pharmacy, 26, 158-167 (2017).

6. A.V. Kenzhebaeva, Int. J. of Applied and Basic Research, 1, 115-119 (2019).

7. D.S. Elagina, N.S. Arkhipova, M.Sh. Sibgatullina, Young Scientists and Pharmacy of the XXI Century, 189-195 (2016).

8. Yu.A. Mazhaisky, S.V. Galchenko, T.M. Guseva, A.S. Cherdakova, Achievements of modern science and education, 9, 203-205 (2016).

9. A.R. Biglova, A.A. Reut, Fruit and berry growing in Russia, 62, 142-151 (2020).

10. A.A. Voronin, O.N. Safonova, The past, present of the botanical garden and its role in science and education, 66-71 (2016).

11. O.A. Simonova, M.V. Simonov, E.V. Tovstik, Tavrichesky Bulletin of Agrarian Science, 3, 142-150 (2020).

12. State Pharmacopoeia of the Russian Federation: in 3 vol. [Electronic resource]. XIII ed. (M., 2015). URL: http://femb.ru/feml (Date of access: 01.11.2020).

13. A.E. Pobilat, E.I. Voloshin, Trace elements in medicine, 18, $43-47$ (2017).

14. T.V. Baikalova, P.C. Baikalov, I.S. Korotchenko, KrasGau Bulletin, 5, 123-130 (2017).

15. MPC of heavy metals in food raw materials and food products. San PiN 42-123-408986 dated 03/31/86.

16. Temporary maximum permissible level (MRL) of some chemical elements and gossypol in feed for farm animals (approved by the Main Veterinary Administration of the State Agro-Industrial Committee of the USSR on August 7, 1987) 